\title{
In-Plant Test and Evaluation of the Neutron Collar for Verification of PWR Fuel Assemblies at Resende, Brazil
}

\author{
H. O. Menlove \\ Marco A. S. Marzo* \\ Silvio G. de Almeida* \\ M. Candida de Almeida* \\ L. Paulo M. Moitta* \\ L. F. Conti* \\ J. Roberto T. de Paiva**
}

$\therefore$ 


\section{CONTENTS}

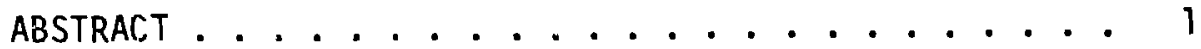

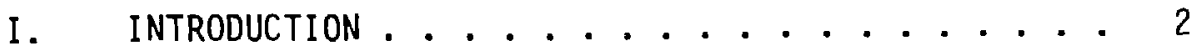

II. DESCRIPTION OF EQUIPMENT AND SETUP ....... 2

A. Neutron Source............ . 2

B. Measurement. Setup ........... 3

C. Electronics ............. 5

III. DESCRIPTION DF FUEL ASSEMBLIES . . . . . . . . 5

IV. MEASUREMENT STEPS ............ 6

A. Initial Check-Out After Shipment ...... 6

B. Check-Out at Facility ......... 6

C. Routine Operation .......... 7

D. Scanning Mode ........... 7

v. CALIBRATION ............. 8

A. External Ábsoiute calibration. $: \cdots$

B. Reference Assembly Calibration ....... 11

VI. IN-PLANT TEST RESULTS ........... 11

A. In-Plant Neutron Backgrounds . . . . . . . 11

B. Response vs Assembly Position . . . . . . 12

C. Scan Results............. 12

D. ANGRA-1 Results . . . . . . . 13

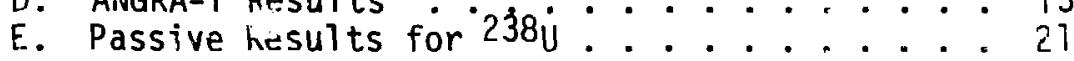

F. Precision and Stability ........ 25

G. ANGRA-II Active Assay . . . . . . . 26

VII. CONCLUSIONS ............. 27

A. Electrical Noise . . . . . . . . . . 27

B. Precision and Stability ....... 27

C. Information from Operator ........ 27

D. On-Line Use Potential .......... 27

E. Inspector Use Evaluation. . . . . . . . 28

ACKNJWLEDGMENTS . . . . . . . . . . . 28

REFERENCES ................. 28

APPENDIX. DATA COLLECTION AND STATISTICAL ANALYSES

PROGRAM USING THE HP-97 CALCULATOR ... . 30 
IN-PLANT TEST AND EVALUATION OF THE NEUTRON COLLAR FOR VERIFICATION OF PWR FUEL ASSEMBLIES AT RESENDE, BRAZIL

by

H. 0. Menlove, Marco A. S. Marzo, Silvio G. de Almeida,

M. Candida rie Almeida, L. Paulo M. Moitta, L. F. Conti, and $\mathrm{J}$, Roberto T. Ca Paivd

\section{ABSTRACT}

The neutron-coincidence collar has bten evaluated for the measurement of pressurized-water reactor (PWR) fuel assemblies at the Fabrica de Elementos Combustiveis plant in Resende, Brazil. This evaluation was part of the cooperative-bilateral-safeguards technical-exchange program between the United States and Erazil. The neutron collar measures the ${ }^{235} \mathrm{U}$ content per unit length of full fuel assemblies using neutron interrogation and coincidence counting. The $238 \mathrm{U}$ content is measured in the passive mode without the AmLi neutron-interrogation source. The extended evaluation took place over a period of 6 moriths with both scanning and single-zone measurements: The results of the tests gave a coincidence-response standard deviation of $0.7 \% \quad(0=1.49 \%$ for mass) ior the active case and $2.5 \%$ for the passive case in 1000-s measurement times. The length measirement in the scanning mode was accurate to $0.77 \%$. The accuracies of different calibration methods were evaluated and compared. 


\section{INTRODUCTION}

As part of the United States-Brazil safeguards technical-exchange activity, a neutron-coincidence collar has been evaluated for the verification of fresh pressurized-water reactor (PWR) fuel assemblies. The work was performed during the period from October 1984 to May 1985 at the Fábrica de Elementus Combustiveis (FEC) plant near Resende, Brazil. The measurements were performed by staff from Comissão Nacional de Energia Nuclear (CNEN) during six separate visits to the plant over a six-month interval.

The neutron collar uses active neutron-interrogation combined with neutron-coincidence counting to measure the ${ }^{235} U$ content in the fuel assembly. The ${ }^{238} \mathrm{U}$ content is determined by the passive coincidence counting of the spontaneous fission rate from the ${ }^{238} \mathrm{U}$ decay. Previous reports ${ }^{1-3}$ give a description of the neutron-coincidence collar and its application to PWR and boiling-water reactor (BWR) fuel assemblies.

The present test was to evaluate the collar under conditions typical for inspector work in the field. These conditions included:

- international shipment of the equipment,

- operation by inspectors with only brief training on the collar,

- multiple setup and disassembly of equipment for each inspection visit,

- hot and humid weather conditions, and

- large voltage fluctuations in the plant.

All 40 assemblies in the plant were measured during the evaluation period, and the results of the work are described in this report.

\section{DESCRIPTION OF EQUIPMENT AND SETUP}

\section{A. Neutron Source}

The neutron source for the present work was MRC-AmLi-11B, contained in the double stainless steel capsule (Model 2724 BT). This source has $0.93 \mathrm{Ci}$ of ${ }^{241} \mathrm{Am}$ in the form of $\mathrm{AnO}_{2}$ with a neutron yield of $5.3 \times 10^{4} \mathrm{n} / \mathrm{s}$ and the Internationai Atomic Energy Agency certification of competent authority USA/ D043/S. Figure 1 shows a schematic drawing of the source.

The radiation dose from the source in the collar was less than the dose from the fuel assembly $(<1 \mathrm{mRem} / \mathrm{h})$. 


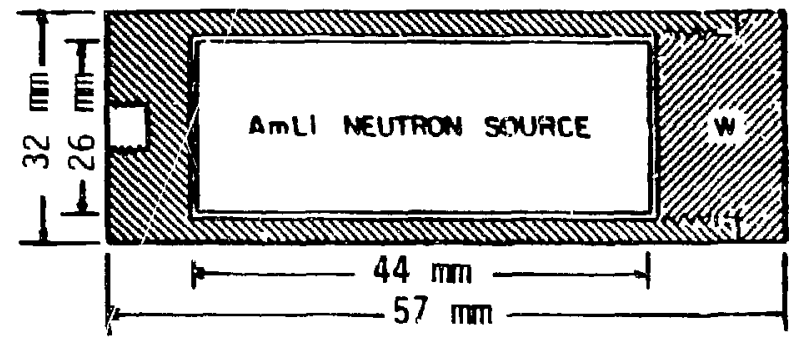

Fig. 1. Schematic diagram of AmLi neutron-source holder.

\section{B. Measurement Setup}

1. Scanning Mode. The neutron collar was used in two different measurement locations. The first location was for scanning the entire length of the assembiy and the second was for use on the normal support cart.

Figure 2 shows the neutron collar

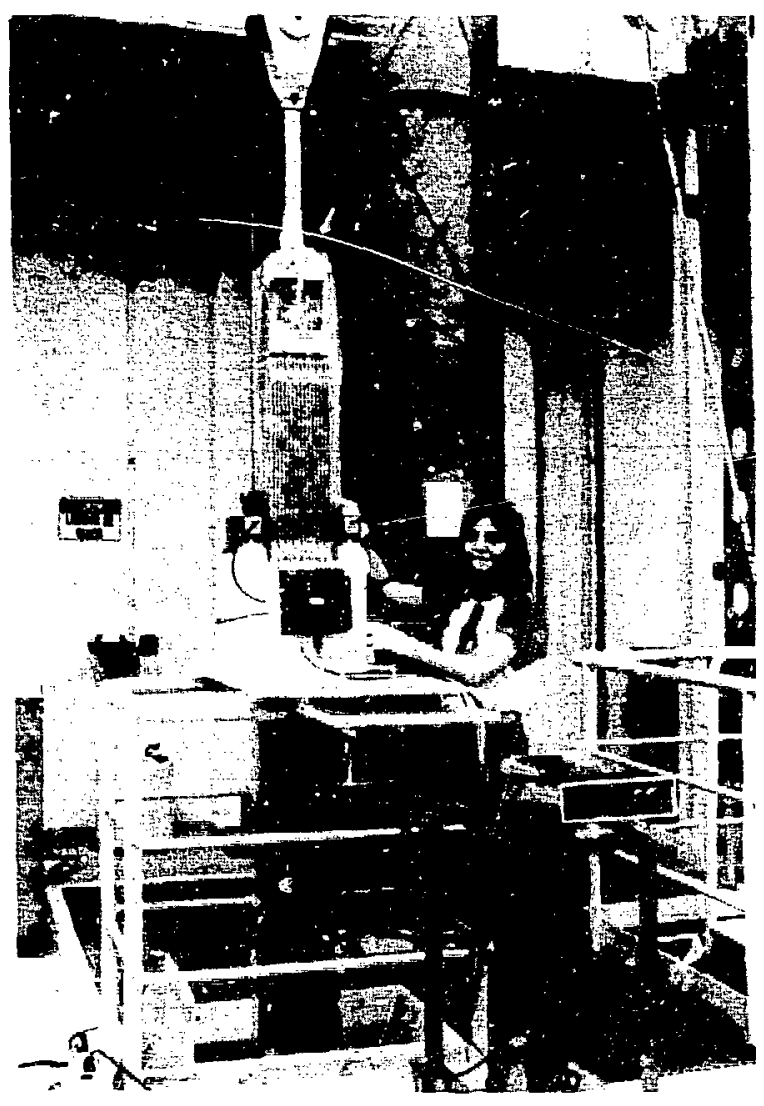

Fig. 2. Neutron-coincidenre collar positioned on scanning platform with ANGRA-I fuel assembly at the FEC plant, Resende, Brazil. on the support platform produced by FEC to make it possitie to scan the fuel assembly completely through she collar. The platform was located over a hole in the floor for examination of fuel assemblies. The fuel assemblies were moved using the overhead crane. It was possibia to slide the platform in the horizontal direction to engage or decouple the collar from the fuel assembly.

2. Cart Mode. The neutron collar was al so used on its standard support cart to verify the fuel assemblies in the fuel storage vault. For these meas... urements, the extended (double) leos were used with the cart to $7 \mathrm{ift}$ the collar high enough to reach the active zone of the fuel. Figure 3 shows the cart and collar during the measurement of a fuel assembly at Resende. 


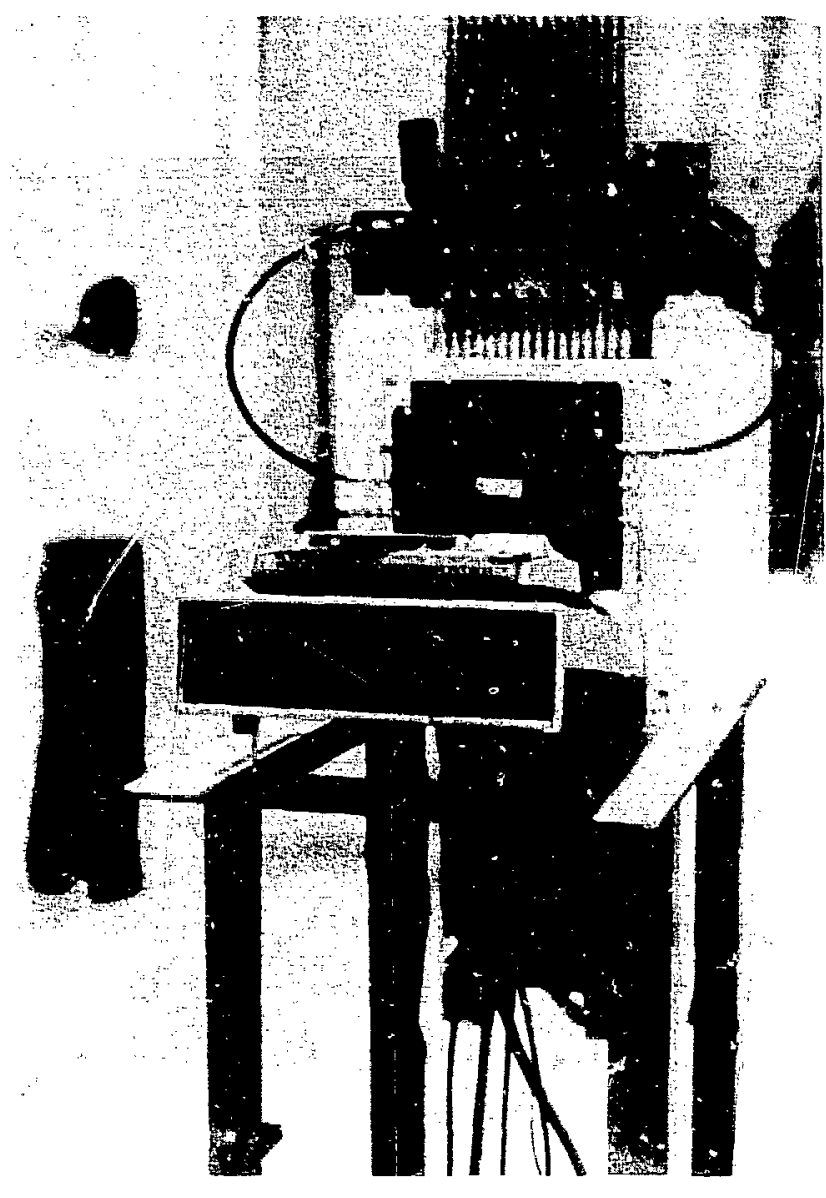

Fig. 3. Neutron $\mathrm{Col}^{3}$ ar and support cart in measurement, position with ANGRA-I fuel asseribly at the FEC plant.

Two different measurement proccdures were used for the fuel assembly verification. For the normal case, the assembilies were transferred to the cart located about $5 \mathrm{~m}$ from the other assembiies. In the second case, the fuel assemblies were not moved, and the cart was moved to the normal assembly storage location. In this case, there were many assemblies in the immediate vicinity of the assembly being measured. This increase in background did not adversely affect the quality of the measurements.

For the measurements, the fuel assemblies were kept inside their p?astic bags to keep them clean. This bag did not affect the measurement results. Foam spacers were used to center the assembly side-to-side and to hold the assembly against the front face (next to the AmLi source) of the collar. This was to improve the positioning reproducibility. Normally, the fuel assembly is positioned $1 \mathrm{~cm}$ back from the front face so that when the present results are compared with the prior calibration results, it will be necessary to correct for this difference in positioning the assemblies. 
In addition to the ANGRA-I fuel assembly results, measurements were performed on a larger ANERA-II assembly containing depleted uranium. This assembly was centered in the collar and both passive and active measurements were performed.

\section{Electronics}

The electronic components are identical to the high-level neutron-coincidence counter (HLNCC). ${ }^{4}$ The recommended settings were used as follows:

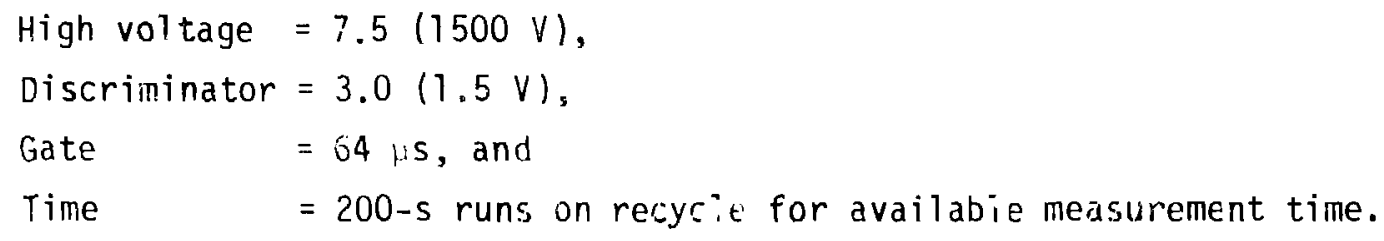

Figure 4 shows the shift register (Model HEC-100 produced by IRT Corp.) and programmable calculator (Model HP-97 produced by Hewlett-Packard Corp.). The software program for the HP-97 is described in the Appendix.

\section{DESCRIPTION OF FUEL ASSEMBLIES}

The ANGRA-I fuel assemblies are of the westinghouse PWR type. Fach has a $16 \times 16$ rod array with 21 control rod positions resulting in 235 fuel rods. The characteristics of the fuel are given in Table $I$.

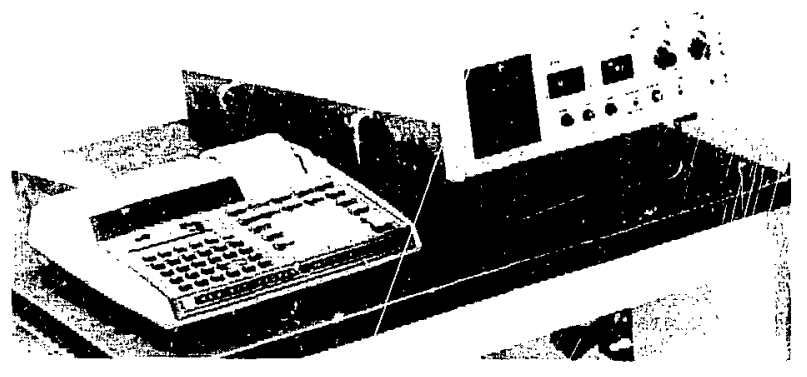

Fig. 4. Shift-register coincidence electronics package i IRT Model HEC$100)$ and progranmable calculator. 
Abl.'."

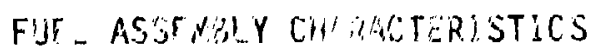

\begin{tabular}{|c|c|c|}
\hline & ANCRA-I & ANGEV $=?$ \\
\hline Arrozy sise & $16 \times 16$ & $16 \times 16$ \\
\hline Fufi rotive Terotil & $36553 \mathrm{~nm}$ & $39,0 \mathrm{rmm}$ \\
\hline Whe at rode & 236 & 206 \\
\hline da juing natertit & Zircäloy-2 & zircaloy $\cdot 2$ \\
\hline Mas $\mathrm{VO}_{2}$ & $497 r_{3} \quad 9$ & $61 \mathrm{~J} 567 \mathrm{~g}$ \\
\hline "lass uraniv" & 332330 & 3407669 \\
\hline $\operatorname{Mass} 2.35$ & $1295 i$ & 11309 \\
\hline Poliet giander & $5.05 \pi$ & $9.13 \mathrm{~mm}$ \\
\hline $\pm 38_{\mathrm{g}}^{\mathrm{s} / \mathrm{cm}}$ & $i 0 ; 4 . ;$ & 1383.8 \\
\hline $\mathrm{g}^{23 \mathrm{~s}} \mathrm{j} / \mathrm{cm}$ & 2,15 & 3.1 \\
\hline ijranium-a 35 errichmo it & $3.50 \%$ & $0.2 \% \%$ \\
\hline $\mathrm{rad}_{2} \mathrm{O}_{3}$ & is ne. & Motre \\
\hline
\end{tabular}

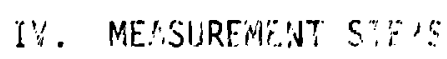

A. Initia i Check (ist difier Shir nont.

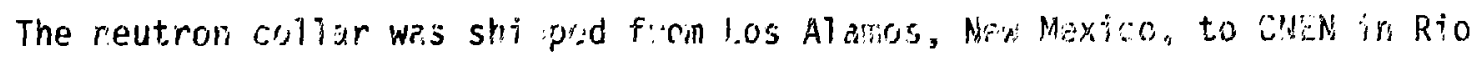
de Janeiyo, Bratl. Pafter ch avinc cusioms, the collar was set up at laboratório de Saíviguardas, lociced at Institutes de Radioprotecăo ï Josimetria (IRD), for dernonstration a'd trdinirg of CNEN staff. The equipinent was moved later by van to the FEC fabricationl plant near Keseride, Biazii.

B. Check.-Out at Facijity

11) Set up the crirt; attach the coliar to the cart or support platform with the chinbscrews.

(2) Attach tins: e? ectronics to the detector as described in Ref. 4 and set the paraneters as listed in Sec. II.C (do not change these settings betweer uses). 
3' iake a 300 ; count with no AmLi source or fuel assembly near the unit. The ret cojlcidenie race $(R+A)$ - $A$, where $(R+A)$ is the reals plus acCidentra ate and $A$ is the accidental race, shouid be statistically bude? tis zers. The totals rate should be between 5 and 600 counts/s, $\therefore$ ispridig on the dirount of $\mathrm{UO}_{2}$ in the vicinity.

14j itae the AmLi source in the collar (no fuel assembly) and take $3 x$ $110-$; $1 r_{i s ;}$ note that the coincidence rate $R$ is statistically zero and the net totrils rate is 01930 for AmLi-118.

\section{Nout'ne speriation}

(1) Pyssive mode (no AmLi) - remove the neutron source and set the time for 200-s recycle with the fuel assembly in the collar.

:2) A.fter the desired number of cycles ( $\sim 5)$, press the stop button on the HEC-100 and the program key $B$ on the HP-97. This will print out the surnmary of the passive results and store the coincidence background data in register $A$ for subtraction from the active assay (see the Appendix).

(3) Active mode (with AmLi) - return the neutron source to the collar and press the start button on the HEC-100 to start the runs.

(4) After the desired number of 200-s runs (25), press the stop button and press the program key $C$ on the HP-97. This will print out the active results.

\section{Scanning Mode}

i1) Attach the collar to the platform over the hole in the floor, ard place the HEC-100 and HP-97 on the support cart.

(2) Request the operator to use the overhead crane to lower the fuel assembly through the collar, stopping when each grid spacer is even with the bottom of the collar. 
(3) Take $n \times 200-5$ recycle counts where $n$ is $1-3$, determined by the availabie measurement time.

(4) Record the assembly position and press key $C$ to get statistical summary at each position.

(5) To verify active length, move the assembly to the one-half maximum pcints (top and bottorn) determined from the calibration scan profile.

(6) Take a short count $(22 \times 100 \mathrm{~s})$ at each end position and compare with the average rate in the middle region of the fuel. Within the counting statistics, the rate should be one-half the full rate.

\section{CALIBRATION}

\section{A. External Absoluce Calibration}

During the past several years, other neutron-coincidence collar's have been calibrated using reference fuel assemblies at Belgium ${ }^{2}$ (PWR), Sweden ${ }^{3}$ (BWK), and Exxon Nuclear (PWR and BWR). A range of ${ }^{235} U$ enrichments was used to establish the shape of the calibration function, and the AmLi neutron sources were measured to establish the relative counting efficiency.

These calibration curves can be used for the fuel in Brazil if the collar responses are normalized using the AmLi neutron sources. This procedur: assurnes that only the counting efficieñcy has changed between calibration and subsequent application.

For the present work, we will normalize to the calibration using a different collar (LANL-1, AmLi-117). This collar has been calibrated at Exxon Nuclear Corp. in Richland, Washington, using two reactor fuel assemblies that are similar to the ANGRA-1 assembilies. The enrichments and fissile linearloading densities are given in Table II.

Prior cross-calibration measurements at Los Alamos established that the collar used in Brazil (LANL-2) gives a coincidence response that is 1.009 times larger than the collar used at Exxon (LANL-1) for the same PWR fuel assembly. 
TABLE II

CALIBRATION OF REFERENCE FUEL AS:EMBLIES

Coinc.

$235 \mathrm{U}$ Ritie

Reactov Array Type $\quad$ (\%) $\mathrm{g}^{235 \mathrm{U} / \mathrm{cm}}$ Collar source $\left(\mathrm{s}^{-1}\right)$

$\begin{array}{lllllll}\text { Exxor-1 } & 14 \times 14 & \text { PiWR } & 3.82 & 38.28 & \text { LANL-1 AmLi-117 } 133.8\end{array}$

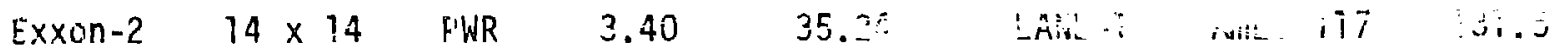

$\begin{array}{llllll}\text { ANGRA-I } & 16 \times 16 \quad \text { FWR } & 3.30 & 35.40 \quad \text { LANL-2 } & \text { imLi-1 } 18 & 135.2\end{array}$

The $235 \mathrm{U}$ mass per unit length is calculated from the calibration function using the expression

$$
M=k_{2} a\left(k_{1} R\right)^{b},
$$

where $a=0.001344$ and $b=2.135$ ror PI:R fuel assemblies. ${ }^{2}$

Figure 5 shows a graph of this calibration function for PWR assemblies.

For the preseit absolute calibration, $k_{2} \equiv 1.000$ and we solve Eq. (i) for $k_{T}$, giving

$$
k_{1}=\frac{1}{R}\left(\frac{M}{a}\right)^{1 / b}
$$

This equation was calculated for the two reference assemblies from Exxon yielding an average value of

$$
k_{1}=0.9024
$$

with $T_{0}=1920$ for the LANL-1 collar, where $T_{0}$ is the net totals rate with no sample present at the time of calibration. 


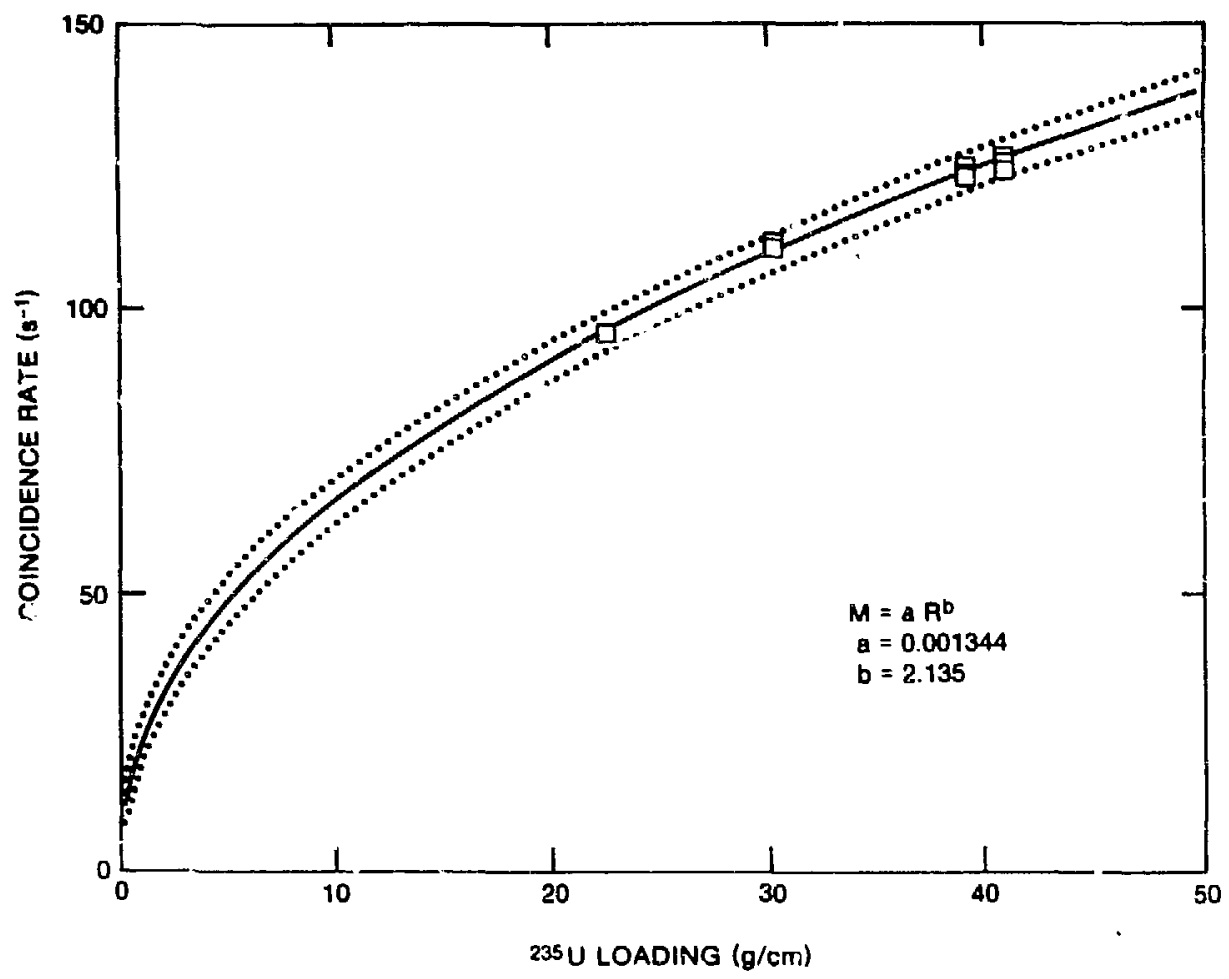

Fig. 5. Calibration curve for standard PWR fuel assemblies $(17 \times 17$ array $)$.

For the Brazil case, $T_{0}=1930$ and the fuel assembly was touching the front face of the collar instead of being in the standard position $10 \mathrm{~mm}$ back. inis increased the response by a factor of 1.017 .

Thus, we can use the $k_{1}$ reference value from Exxon for Brazil if we correct it as follows:

$$
\begin{aligned}
& k_{1}=\underbrace{0.9024}_{\begin{array}{l}
\text { Exxon } \\
\text { ref. }
\end{array}} \times \underbrace{(3.017)^{-1}}_{\begin{array}{l}
\text { position } \\
\text { corr. }
\end{array}} \times \underbrace{(1.009)^{-1}}_{\begin{array}{l}
\text { efficiency } \\
\text { corr. }
\end{array}}, \\
& k_{1}=0.8794 \text { for LANL-2. }
\end{aligned}
$$

The two AmLi sources have the same neutron yields. 
The calibration is more simple and direst if we use one of the fuel assemblies at the facility as a calibration reference assembly. Then the other assemblies are measured relative to the reference assembly'. We: selected assembly KWU-1 as the reference assembly for the ANGRA-1 fuel.

In this case, $k_{1} \equiv 1.000$ and $k_{2}$ is measured during each visit using the equation

$$
k_{2}=\frac{M}{a} \frac{1}{(R)^{b}}
$$

where $M$ is the operator's value $\left(g^{235} \mathrm{U} / \mathrm{cm}\right.$ ) for $\mathrm{KWU}-1$ and $R$ is the average response for the reference assembly that was measured during each visit.

A. In-Plani Neutron Backgrounds

The primary source of neutron background in the fabrication plant is the $\mathrm{UO}_{2}$ in the fuel assemblies. This background was measured in each of the collar locations, and the results are listed in Table III.

TAELE III

IN-PLANT NEUTRON BACKGROUNDS

\section{Location}

scanning pit

Storage vault - away from fuel

Storage vauli - next to fuel

KWU-] fuel assembly (net)

$$
\text { Totals Rate }
$$

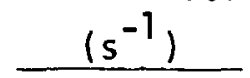

4

66

น200

114
Coincidence Rate

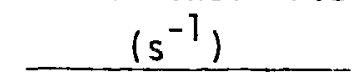

\section{0}

0

0

7.22 
The totals background is not important except for determining the net totals rate $T_{0}$ for calibration purposes. The totals background rate from a singie ANGRA-1 PWR assembly in the collar was measured to be $114 \mathrm{~s}^{-1}$, and this rate was "sed in the correction for the induced fissions from room neutrons.

3. Response "s Assembly Position

To determine the change in response for different fuel positions, the assembly KWU-1 was counted in the middle of the collar as well as in positions touching the iront and back of the collar. The front-to-back response gradient was measured to be $1.7 \% / \mathrm{cm}$. The normal position for calibration of a PWR fuel assembly is $1 \mathrm{~cm}$ back from the front face of the collar, but for the ANGRA-1 fuel we measured the assemblies touching the front face. Thus, the coincidence rate must be reduced by the factor 1.017 to correspond to the normal calibration parameters.

When a fuel-assembly spacer grid is in the measurement zone, there will be a slight reduction in the response because the fue $i$ is pushed away from the neutron source by $\sim 3 \mathrm{~mm}$. This will reduce the response by $\sim 0.5 \%$; however, all of the measurements for ANGRA-1 fuel were made with the collar between the spacer grids.

The active length of the fuel assembly must extend at least $15 \mathrm{~cm}$ beyond the bottom or top of the collar to avoid a reduction in the measured response because of and losses from neutron leakage.

\section{Scan Results}

During the first measurement visit to FEC, we made a full length scan of assembly KWU-1 using the overhead crane to move the fuel assembly. Measurements were made about $50 \mathrm{~cm}$ apart to give the response profile shown in Fig. 6 . The individual measurement times were normally $2 \times 100 \mathrm{~s}$.

The full width at half maximum (FWHM) in the profile gives a measure of the active length for the fuel. The result for $\mathrm{kWW}-1$ was $363 \pm 2 \mathrm{~cm}$, which can be compared with the operator's value of $365.8 \pm 0.6 \mathrm{~cm}$, giving a difference of $0.77 \%$ in the length measurement. This uncertainty can be reduced to $0.3 \%$ using the collimated HM-4 gamma-ray instrument. ${ }^{5}$ 


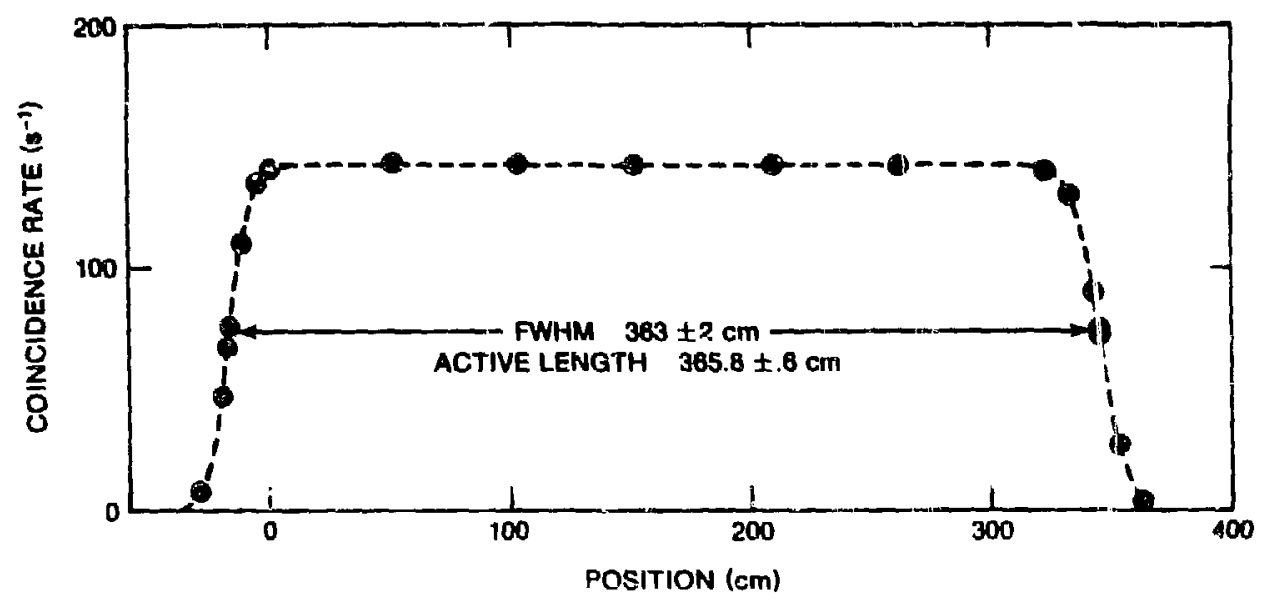

Fig. 6. ANGRA-I filel assembiy coincidence scan profile using the neutron collar.

D. ANGRA-1 Results

We will analyze the data using three different calibration approaches:

(1) Plant reference assembly with renormalization on each visit,

(“) Absolute calibration with Exxon fuel assemblies and renormalization using the AmLi source (AmLi-118) during each visi $i$, and

(3) No normalization for each visit, using a single value of $k_{1}$ for the entire exercise.

There were six separate visits to the plant during the six-month measurement program for ANGRA-1. Table IV gives a summary of the calibration param. eters used for the above three methods. The net totals rate with no sample present $\left(T_{\text {new }}\right)$ was measured during each visit.

For method $?, k_{1} \equiv 1.000$ and $k_{2}$ is obtained from the different measurements of the reference assembly from the six visits listed in Table IV. For metiod 2, $k_{2} \equiv 1.000$ and $k_{1}$ is obtained from AmLi source reference from six values listed in Table IV. For method $3, k_{2} \equiv 1.000$ and the single absolute value of $k_{1}=0.8794$ is used. 
TABLE IV

CALIBRATION PARAMETERS

Visit

\begin{tabular}{|c|c|c|c|c|c|c|c|}
\hline & 1 & 2 & 3 & 5 & 5 & 6 & Average \\
\hline KWU- 1 rate & 132.8 & 136.5 & 134.1 & 137.3 & 135.0 & 135.6 & 135.2 \\
\hline 2 & 0.7719 & 0.7285 & 0.7560 & 0.7189 & 0.7453 & 0.7383 & 0.7430 \\
\hline$T_{\text {new }}$ & 1930 & 1931 & 1930 & 1959 & 1933 & 1926 & 1934 \\
\hline$k_{1}$ & 0.8794 & 0.8785 & 0.8794 & 0.8532 & 0.8762 & 0.8826 & 0.8749 \\
\hline
\end{tabular}

1. Normalization Method 1 Using Plant Reference Assembly. In principle, this is the most accurate calibration procedure because potential variations in both the counting efficiency and interrogation flux are corrected. The reference assembly (KWI-1) was counted several times during each visit and the mean coincidence response was used to obtain

$$
k_{\hat{c}}=\frac{M}{a(R)^{b}} \text {, }
$$

where $M=35.4 \mathrm{~g}^{235} \mathrm{U} / \mathrm{cm}$ and the values of $R$ and $k_{2}$ are given in Table IV. The mass $(g 235 \mathrm{U} / \mathrm{cm})$ for each of the other fuel assemblies was obtained using the above equation.

Table $V$ gives the summary of the active-assay coincidence rates for each of the six visits. No normalization to the reference assembly has been applied to these rates. We see that both the reference rate and the assay rates are about $1.5 \%$ high for visit number 4 . The observed scatter or standard deviation in the average coincidence rates was $1.2 \mathrm{~s}^{-1}$ or $0.88 \%$ without any normalization. This deviation can be compared with the expected value from only counting statistics of $\sigma=0.70 \%$ for a measurement of $5 \times 200 \mathrm{~s}$. 
TABLE V

COINCIDENCE RATES FOR ANGRA-I FUEL ASSEMBLIES

\begin{tabular}{|c|c|c|c|c|c|c|c|}
\hline $\begin{array}{c}\text { Assembly } \\
\text { No. }\end{array}$ & $\begin{array}{c}1 \\
12-12-84\end{array}$ & $\begin{array}{c}2 \\
01-23-85 \\
\end{array}$ & $\begin{array}{c}3 \\
02-04-85 \\
\end{array}$ & $\begin{array}{c}4 \\
02-26-85 \\
\end{array}$ & $\begin{array}{c}5 \\
03-11-85 \\
\end{array}$ & $\begin{array}{c}6 \\
05-0^{7}-85 \\
\end{array}$ & Average \\
\hline $\begin{array}{r}\text { KWU- } \\
2 \\
3 \\
4 \\
4 \\
5 \\
6 \\
7 \\
8 \\
9 \\
10 \\
11 \\
12 \\
13 \\
14 \\
15 \\
16 \\
17 \\
18 \\
19 \\
20 \\
21 \\
22 \\
23 \\
24 \\
25 \\
26 \\
27 \\
28 \\
29 \\
30 \\
31 \\
32 \\
33 \\
34 \\
35 \\
36 \\
37 \\
38 \\
39 \\
40\end{array}$ & $\begin{array}{l}132.8 \\
132.9 \\
132.7 \\
135.9 \\
136.5 \\
136.1 \\
139.1 \\
134.5\end{array}$ & $\begin{array}{l}136.5 \\
135.0 \\
134.2 \\
136.2 \\
137.8 \\
133.9 \\
138.2\end{array}$ & $\begin{array}{l}136.2 \\
136.2 \\
134.5 \\
137.3 \\
135.9 \\
138.7 \\
134.6 \\
135.9 \\
135.5 \\
133.2 \\
132.5 \\
135.1 \\
135.5\end{array}$ & $\begin{array}{l}137.4 \\
138.8 \\
138.2 \\
135.0 \\
137.0 \\
136.6 \\
135.5 \\
136.3 \\
137.9 \\
135.9 \\
136.9 \\
138.8 \\
137.4 \\
136.4\end{array}$ & $\begin{array}{l}135.0 \\
136.8 \\
134.8 \\
134.7 \\
135.0 \\
135.8 \\
135.4\end{array}$ & $\begin{array}{l}137.5 \\
135.1\end{array}$ & $\begin{array}{l}135.2 \\
134.9 \\
133.9 \\
135.6 \\
136.4 \\
135.3 \\
136.7 \\
136.2 \\
134.5 \\
137.3 \\
136.7 \\
136.3 \\
134.6 \\
135.9 \\
135.5 \\
133.2 \\
133.5 \\
135.1 \\
135.5 \\
137.4 \\
137.4 \\
138.2 \\
135.0 \\
137.1 \\
136.6 \\
135.5 \\
136.3 \\
137.9 \\
135.9 \\
136.9 \\
136.5 \\
137.4 \\
136.4 \\
135.2 \\
134.8 \\
133.9 \\
135.2 \\
136.9 \\
136.4 \\
136.0\end{array}$ \\
\hline Average & $\begin{array}{c}134.8 \\
\pm 2.3\end{array}$ & $\begin{array}{c}136.2 \\
\quad \pm 1.4\end{array}$ & $\begin{array}{r}i 35.1 \\
\quad \pm 1.8\end{array}$ & $\begin{array}{c}137.7 \\
\pm 1.1\end{array}$ & $\begin{array}{c}135.3 \\
\pm 1.0\end{array}$ & $\begin{array}{c}135.3 \\
\pm 1.1\end{array}$ & $\begin{array}{r}135.9 \\
\pm 1.2\end{array}$ \\
\hline
\end{tabular}


When the measured $R$ is converted to mass (M) using Eq. (1), the per cent error in $R$ is increased by approximately the factor $b=2.135$ because

$M \propto R^{b}$,

and

$\Delta M \propto b \Delta R$.

Table VI gives the operator's tag value for the mass $\left(g^{235} \mathrm{U} / \mathrm{cm}\right)$ of each assembly, together with the measured value using the neutron collar. The $k_{2}$ factors listed in Table IV were used in Eq. (1) to calculate M.

The average absolute value of the mass residual was $1.49 \%$, which compares very well with the sti. $\therefore$ tical expectation of $v_{b \sigma} r^{\%} \simeq 2.135(0.70)=1.49 \%$ for single measurements of $1000 \mathrm{~s}$. For those assemblies where we have used the average of several measurements, the expected statistical error will decrease; nowever, the value of $\sigma_{r}=0.70 \%$ includes oniy the active coincidence-rate statistical error, but the net corrected coincidence error also should inciude the uncertainties from the passive background subtraction and the reference-normalization measurements.

Figure 7 shows a histogram of the active assay results for the 39 ANGRA-1 fuel assemblies. The mean value for the distribution is $35.6 \mathrm{~g} 235 \mathrm{lj} / \mathrm{cm}$ and 36 of the values fall within $\pm 2 \sigma$ where $\sigma$ is $1.5 \%$. The average mass for the operator's tag values is 35.40 , resulting in a small difference of $0.56 \%$ compared with the measured values.

2. Normalization Method 2 Using AmLi Neutron Source. An absolute value for the mass of the assemblies can be obtained by using prior calibration parameters and using the AmLi source to normalize to the operating conditions at FEC. Only the totals rate is obtained from the AmLi (no coincidence neutrons), and the totals rate is proportional to the efficiency

$$
T \alpha \varepsilon .
$$


TABLE VI

MASS RESULTS USING REFERENCE FUEL ASSEMBLY

(Meihod 1 )

Fuel ETements Tag Data $\left(M_{0}\right)$

KWU-1

2

3

4

5

7

8

10

11

12

13

14

15

16

17

18

19

20

21

22

24

25

26

27

28

29

30

31

32

33

34

35

36

37

38

40

Average
35.40

35.42

35.42

35.46

35.60

35.63

35.63

35.60

35.53

35.55

35.54

35.54

35.42

35.39

35.41

35.38

35.34

35.30

35.26

35.25

35.24

35.27

35.33

35.39

35.36

35.31

35.30

35.31

35.39

35.45

35.44

35.45

35.42

35.34

35.34

35.33

35.34

35.34

35.35

35.40

$\underset{\text { CEq. (1) }}{\operatorname{Collar} \text { Results }}(\bar{M})$ Deviation $\left(\frac{\bar{M}-M_{0}}{M_{0}} \times 100\right) \%$

35.40

35.49

34.93

35.89

36.48

35.72

36.92

36.59

35.62

36.80

36.45

36.58

35.68

36.42

36.19

34.89

34.65

35.96

36.19

35.45

35.90

35.90

34.15

35.29

35.02

34.42

34.85

35.73

34.63

35.18

35.43

35.45

35.91

35.51

35.29

34.79

35.51

36.02

36.19

35.96

35.61

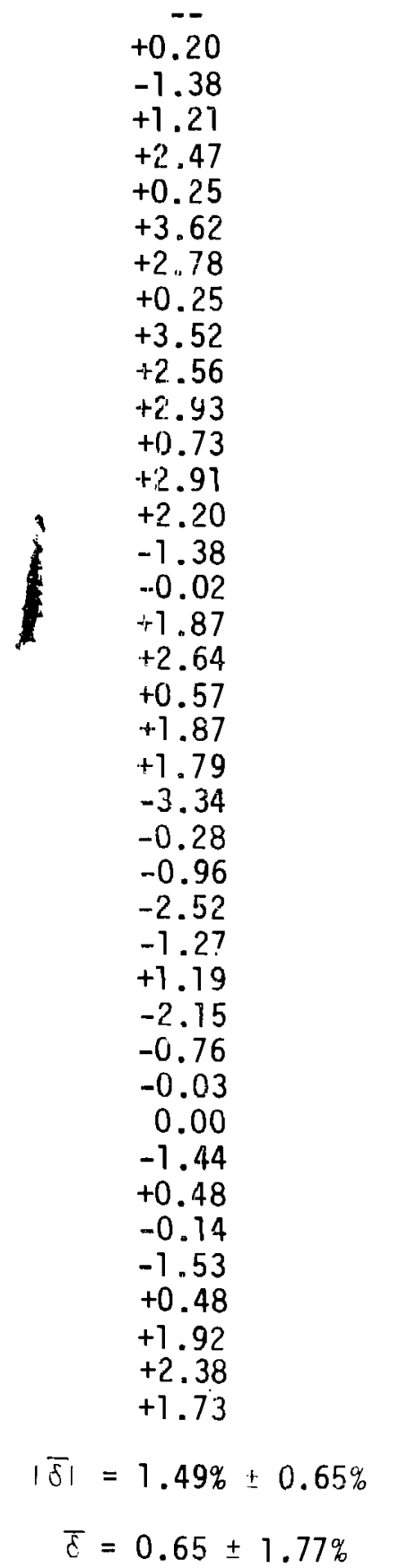




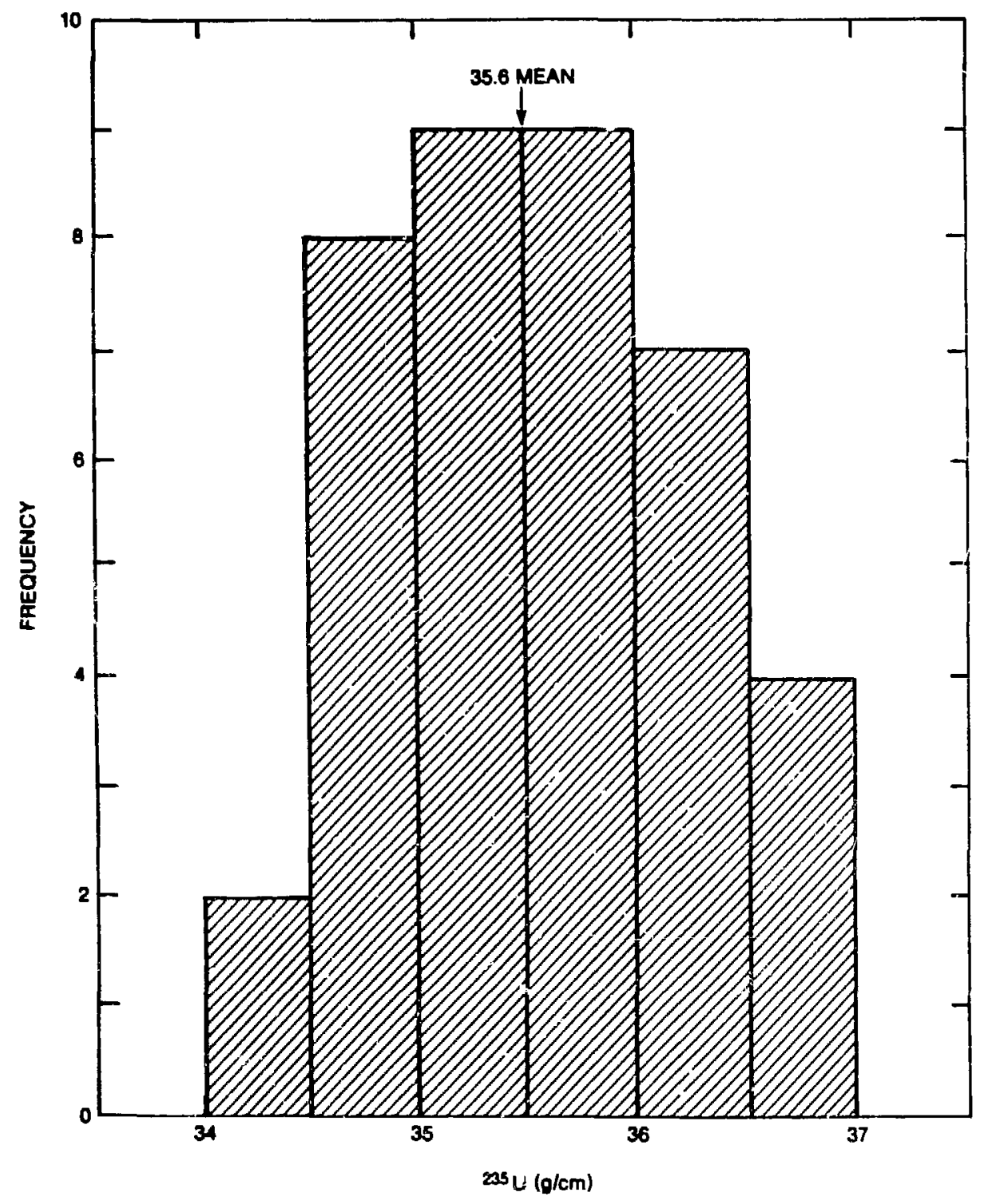

Fig. 7. Histogram distribution for the assay results using calibration method 1 . 
However, the coincidence counting rate varies as the square of the efficiency

$$
R \propto E^{2} .
$$

Thus, if the couiting efficiency has changed, we can correct to the original rate $R_{0}$ with tho equation

$$
R_{0}=R_{\text {, EW }}\left(\frac{T_{0}}{T_{\text {new }}}\right)^{2} .
$$

For the collar used at FEC (LANL-2, AmLi-118), $k_{1}=0.8794$ and $T_{0}=1930$ $s^{-1}$ (see Sec. V.A). When the AmLi totals rates measured during each visit (see Table IV) are used to obtain the mass from the equation

$$
M=(1.000) a\left(k_{1} R\right)^{b},
$$

where

$$
k_{1}=0.8794\left(\frac{1930}{T_{\text {new }}}\right)^{2} \text {, }
$$

we obtain an assay that is independent of the plant's "eference assembly.

Table VII lists the mass values caiculated with Eq. (2) and the comparison with the operator's tag values. The averaye absolute mass residual is $2.13 \%$, which is larger than the averags mass residual of $1.49 \%$ obtained with the nor- . malization to the reference assembly (KW(j-1).

If we take the average assay value of $35.76 \mathrm{~g}^{235} \mathrm{U} / \mathrm{cm}$ and compare it with the average tag value of 35.40 , we get a bias of only $1.07 \%$. This is very good 


\begin{tabular}{|c|c|c|c|}
\hline Fuel Elements & Tag Data $\left(M_{0}\right)$ & $\begin{array}{c}\text { Collar Results (M) } \\
\text { (Eq.2) }\end{array}$ & Deviation $\left(\frac{\bar{M}-M_{0}}{M_{0}} \times 100\right) \%$ \\
\hline $\begin{array}{r}K W U-1 \\
2 \\
3 \\
4 \\
5 \\
6 \\
7 \\
7 \\
8 \\
9 \\
10 \\
11 \\
12 \\
13 \\
14 \\
15 \\
16 \\
17 \\
18 \\
19 \\
20 \\
21 \\
22 \\
23 \\
24 \\
25 \\
26 \\
27 \\
28 \\
29 \\
30 \\
31 \\
32 \\
33 \\
34 \\
35 \\
36 \\
37 \\
38 \\
39 \\
40\end{array}$ & $\begin{array}{l}35.40 \\
35.42 \\
35.42 \\
35.46 \\
35.60 \\
35.63 \\
35.63 \\
35.60 \\
35.53 \\
35.55 \\
35.54 \\
35.54 \\
35.42 \\
35.39 \\
35.41 \\
35.38 \\
35.34 \\
35.30 \\
35.2 . \\
35.25 \\
35.24 \\
35.27 \\
35.33 \\
35.39 \\
35.36 \\
35.31 \\
35.30 \\
35.31 \\
35.39 \\
35.45 \\
35.44 \\
35.45 \\
35.42 \\
35.34 \\
35.34 \\
35.3 .3 \\
35.34 \\
35.34 \\
35.35 \\
35.35\end{array}$ & $\begin{array}{l}35.82 \\
35.47 \\
35.36 \\
36.33 \\
36.80 \\
36.13 \\
37.07 \\
36.79 \\
35.81 \\
36.62 \\
37.23 \\
37.34 \\
35.87 \\
36.62 \\
35.39 \\
35.08 \\
35.39 \\
36.16 \\
36.39 \\
35.14 \\
36.41 \\
35.58 \\
33.8 \\
34.98 \\
34.70 \\
34.11 \\
34.54 \\
35.41 \\
34.33 \\
34.87 \\
35.92 \\
35.14 \\
34.60 \\
35.93 \\
35.71 \\
35.20 \\
35.93 \\
36.45 \\
36.62 \\
36.39\end{array}$ & $\begin{array}{l}+1.19 \\
+0.14 \\
-0.17 \\
+2.45 \\
+3.37 \\
+1.40 \\
+4.04 \\
+3.34 \\
+0.79 \\
+3.01 \\
+4.76 \\
+5.06 \\
+1.27 \\
+3.48 \\
+2.77 \\
-0.85 \\
+0.14 \\
+2.44 \\
+3.20 \\
-0.31 \\
+3.32 \\
+0.88 \\
-4.22 \\
-1.16 \\
-1.37 \\
-3.40 \\
-2.15 \\
+0.28 \\
-3.00 \\
-1.64 \\
+1.35 \\
-0.87 \\
-2.32 \\
+1.67 \\
+1.05 \\
-0.37 \\
+1.67 \\
+3.14 \\
+3.59 \\
+2.94\end{array}$ \\
\hline Average & 35.40 & 35.76 & $\begin{aligned}|\bar{\delta}| & =2.13 \% \pm 1.01 \% \\
\bar{\delta} & =1.008 \pm 2.33 \%\end{aligned}$ \\
\hline
\end{tabular}


considering that the calibration constant $k_{1}=0.8794$ was obtained from a different collar (LANL-1) calibrated at Exxon. In general, this agreement was fortuitous and the absolute calibration will not be this good when using the Aml.i neutron source normalization method.

3. Normalization Method 3 Using a Constant $k$ Coefficient for the Entire Program. In this case we will use the initial Exxon value of $k_{1}=0.8794$ $\left(k_{2} \equiv 1.000\right)$ for the entire program. That is, we will not renormalize the results for each visit. This would be the correct approach if we assume there were no changes in the electronics or collar setup and efficiency during the six-month progran.

The results of this analysis are given in Table VIII. In this case, the average absolute mass residual is $3.29 \%$, which is good considering there was no normalization required. The average value for assay mass was $36.57 \mathrm{~g} 235 \mathrm{U} /$ $\mathrm{cm}$, which is $3.3 \%$ greater than the average of the operator's tag values. The standard deviation in the mass residuals was only $2.0 \%$.

In summary, the equipment and electronics were very stable during shipment to Brazil and during the six-month test program. This resulteu in reasonably good results without any renormalization. However, the results were significantly improved with calibration methods 1 and 2 .

E. Passive Results for ${ }^{238} \mathrm{U}$

In addition to the active interrogation measurement, the passive coincidence rate is proportional to the spontaneous fission rate in the ${ }^{238} \mathrm{U}$. However, this rate is amplified by fast-neutron multiplication in enriched ${ }^{235} \mathrm{U}$. so a correction based on enrichment must be made to obtain the ${ }^{238} U$ mass.

Table IX gives a summary of the passive results. The net coincifence rate $R(n e t)$, corresponds to the measured value corrected for induced fissions from the room background neutrons. This correction is obtained from an ernpirical relationship that is programmed into the HP-97 calculator as follows:

$R($ corrected $)=R($ meas. $)-0.014(T-114)$, 


\section{Fuel Elements Tag Data $\left(M_{0}\right)$}

KWU-1

2

3

4

5

6

7

8

9

10

11

12

$13^{\circ}$

14

15

16

17

18

19

20

21

22

23

24

25

26

27

28

29

30

31

32

33

34

35

36

37

38

39

40

$$
35.40
$$

35.42

35.42

35.46

35.60

35.63

35.63

35.60

35.53

35.55

35.54

35.54

35.42

35,39

35.41

35.38

35.34

35.30

35.26

35.25

35.24

35.27

35.33

35.39

35.36

35.31

35.30

35.31

35.39

35.45

35.44

35.45

35.42

35.34

35.34

35.33

35.34

35.34

35.35

35.35

35.40
Collar Results (M) $\left(k_{1}=0.8794\right)$
36.2.1

36.04

35.47

36.44

35.90

36.7

37.02

36.79

35.81

36.62

37.08

37.19

35.87

36.62

36.39

35.08

34.69

36.16

36.39

37.48

37.48

37.95

36.10

37.31

37.02

36.39

36.85

37.78

36.62

37.19

36.96

37.48

36.90

36.21

35.99

35.47

36.21

36.73

36.90

36.67
Deviation $\frac{\bar{M}-M_{0}}{M_{0}} \times 100 \%$

$+2.29$

$+1.75$

$+0.14$

$+2.76$

$+3.65$

$+1.80$

$+4.07$

$+3.34$

$+0.79$

$+3.01$

$+4.33$

$+4.64$

$+1.27$

$+3.48$

$+2.77$

$-0.85$

$-1.84$

$+2.35$

$+3.20$

$+6.33$

$+6.36$

$+7.60$

$+2.18$

$+5.43$

$+4.69$

$+3.06$

$+4.39$

$+7.00$

$+3.78$

$+4.91$

$+4.29$

$+5.73$

$+4.12$

$+2.46$

$+1.84$

$+0.40$

$+2.46$

$+3.93$

$+4.38$

$+3.73$

36.57 $|\bar{\delta}|=3.29 \% \pm 2.02 \%$

$\delta=3.22 \pm 2.02 \%$ 
TABLE IX

PASSIVE RESULTS FOR ANGRA-1 FUEL ASSEMBLIIES

\begin{tabular}{|c|c|c|c|c|}
\hline ssembly No. & Visits & $\bar{T}$ & $\bar{R}$ (meas.) & $\bar{R}($ net $)$ \\
\hline KWU-1 & $1-6$ & 186 & 8.23 & 7.22 \\
\hline 2 & $1,2,5$ & 190 & 8.63 & 7.57 \\
\hline 3 & $1,2,5$ & 185 & 8.51 & 7.52 \\
\hline 4 & $1,2,5$ & 189 & 8.27 & 7.22 \\
\hline 5 & $1,2,5$ & 187 & 8.42 & 7.40 \\
\hline 6 & $1,2,5$ & 193 & 8.26 & 7.15 \\
\hline 7 & $1,2,5$ & 195 & 8.38 & 7.19 \\
\hline 8 & 3 & 225 & 8.65 & 7.10 \\
\hline 9 & 3 & 226 & 9.00 & 7.43 \\
\hline 10 & 3 & 186 & 8.07 & 7.06 \\
\hline 11 & 3,6 & 188 & 8.35 & 7.31 \\
\hline 12 & 3,6 & 186 & 8.41 & 7.40 \\
\hline 13 & 3 & 188 & 8.09 & 7.05 \\
\hline 14 & 3 & 186 & 8.26 & 7.25 \\
\hline 15 & 3 & 186 & 8.12 & 7.11 \\
\hline 15 & 3 & 189 & 8.53 & 7.48 \\
\hline 17 & 3,6 & 183 & 8.73 & 7.76 \\
\hline 18 & 3 & 188 & 8.35 & 7.31 \\
\hline 19 & 3 & 187 & c..20 & 7.18 \\
\hline 20 & $\Delta$ & 187 & 8.25 & 7.23 \\
\hline 21 & 4,6 & 186 & 8.36 & 7.37 \\
\hline 22 & 4 & 185 & 8.20 & 7.21 \\
\hline 23 & 4 & 185 & 8.48 & 7.49 \\
\hline 24 & 4 & 185 & 8.18 & 7.19 \\
\hline 25 & 4 & 187 & 8.28 & 7.26 \\
\hline 26 & 4 & 185 & 8.2 .7 & 7.28 \\
\hline 27 & 4 & 185 & 8.39 & 7.40 \\
\hline 28 & 4 & 185 & 8.10 & 7.11 \\
\hline 29 & 4 & 182 & 8.07 & 7.12 \\
\hline 30 & 4 & 181 & 8.82 & 7.88 \\
\hline 31 & 4 & 185 & 8.36 & 7.37 \\
\hline 32 & 4 & 186 & 8.45 & 7.44 \\
\hline 33 & 4 & $18 \kappa$ & 8.14 & 7.13 \\
\hline 34 & 5 & $i 79$ & 8.05 & 7.14 \\
\hline 35 & 5 & 177 & 8.14 & 7.26 \\
\hline 36 & 5 & 177 & 8.32 & 7.45 \\
\hline 37 & 5 & 178 & 8.04 & 7.14 \\
\hline 38 & 5 & 177 & 8.19 & 7.31 \\
\hline 39 & 5 & 178 & 7.97 & 7.07 \\
\hline \multirow[t]{2}{*}{40} & 5 & 180 & 8.25 & 7.33 \\
\hline & & & $\begin{array}{c}8.32 \\
\pm 2.69 \%\end{array}$ & $\begin{array}{r}7.30 \\
\pm 2.5 \%\end{array}$ \\
\hline
\end{tabular}


where $T$ is the measured totals rate, $114 \mathrm{~s}^{-1}$ is the background rate from the ANGRA. I PWR fuel, and 0.014 is an empirical constant. The difference (T - 114) is just the net room-background neutrons that. cause the induced fissions.

Mieasirements were performed on four fuel assemblies located in the dense storage area (that is, with adjacent fuel assemblies). The R(meas.) increased to about io but the $R$ (corrected) value was the same as in the open areas $\left(27.3 \mathrm{~s}^{-1}\right)$.

Because all of the fuel assemblies have about the same $g^{238} \mathrm{U} / \mathrm{cm}$ and ${ }^{235} \mathrm{U}$ enrichment, the passive coincidence rate should be the same within statistics. The mean value for $R$ (corrected) $=7.30 \pm 0.18$ and the standard deviation in the scatter was 2.5\%. This scatter can be compared with the expected value from counting statistics of

$$
\begin{aligned}
\sigma \% & =\frac{\sqrt{(R+A)+A}}{R(p a s s i v e)} \times 100 \%, \\
& =1.4 \% \text { for } 1000 \mathrm{~s} .
\end{aligned}
$$

Many of the passive background runs were for less than $1000 \mathrm{~s}$, and this accounts for part of the increase in the observed szatter. Also, the empirical correction for room-background induced fission causes some additional uncertainty.

Figure 8 shows the passive results as a function of enrichment for ANGRA-1 and ANGRA-2 fuel. The coincidence rate increases as the enrichment increases because of neutron multiplication in the ${ }^{235} \mathrm{U}$. We have used the previous data from PWR assemblies in Belgium ${ }^{2}$ to extrapolate the response to zero enrichment.

After correcting the data for induced fissions in the ${ }^{235} U$, we have plotted the corrected passive response vs the ${ }^{238} \mathrm{U}$ content. These results are shown in Fig. 9.

The primary goal of the passive measurement is to check the ${ }^{238} U$ and to give an independent value for the ${ }^{235} \mathrm{U}$ enrichment from the equation 


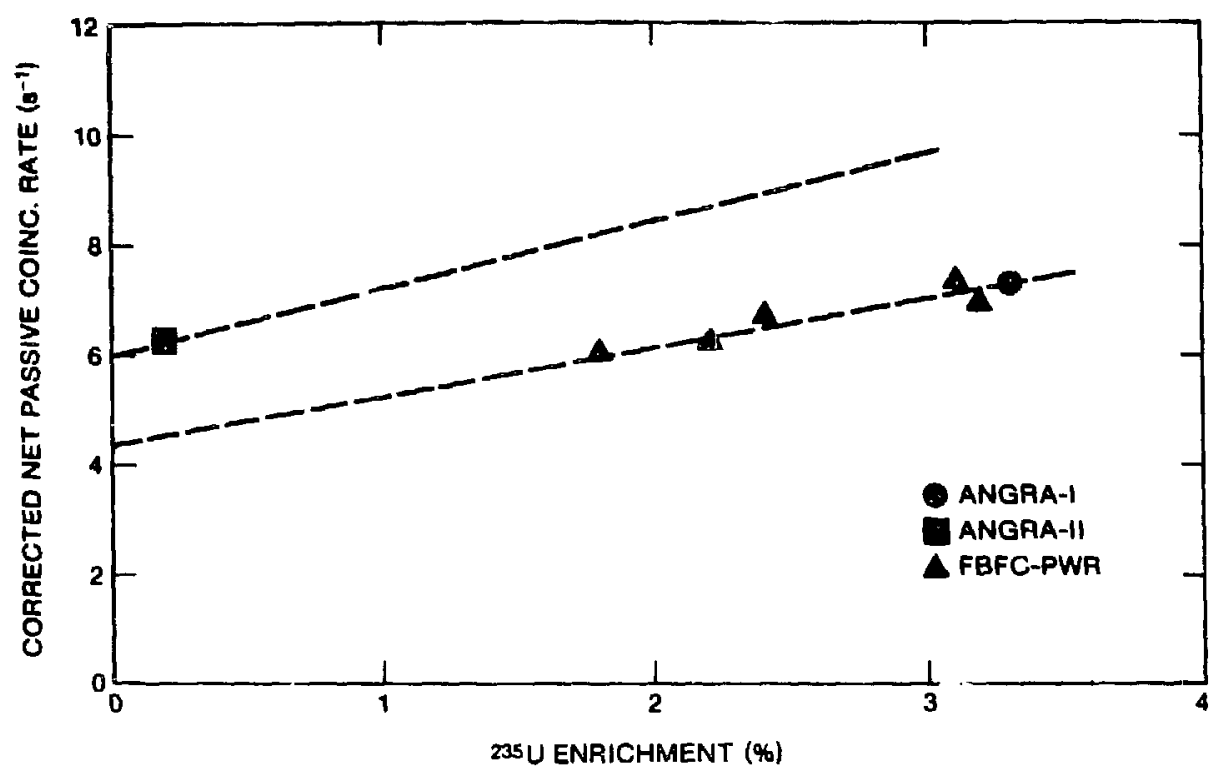

Fig. 8. Net passive coincidence rates as a function of enrichment for ANGRA-I and ANGRA-II fuel assemblies and Belgium fuel.

${ }^{235} \mathrm{U}($ Enrichment $)=\frac{\mathrm{g}^{235} \mathrm{U} / \mathrm{cm}}{\mathrm{g}^{235} \mathrm{U} / \mathrm{cm}+\mathrm{g}^{238} \mathrm{U} / \mathrm{cm}}$.

This value is used only to check the operator's declaration of total uranium because the passive measurement has a relatively large uncertainty. An additional benefit of the passive measurement is that it prevents the undetected substitution of moderator rods for $\mathrm{UO}_{2}$ rods. A substitution of moderator rods for $\mathrm{UO}_{2}$ will calse a drop in the passive coincidence rate.

F. Precision and Stability

The precision and stability of the equipment was demunstrated by the standard deviation in the results of methods 1-3 described in the preceding sections.

In addition to these results, we have repeat measurements on a single assembly counted overnight to obtain good statistical precision. The assembly KWU-1 was measured $9 \times 6000 \mathrm{~s}$, resulting in an observed scatter of $0.55 \%$ (10) 


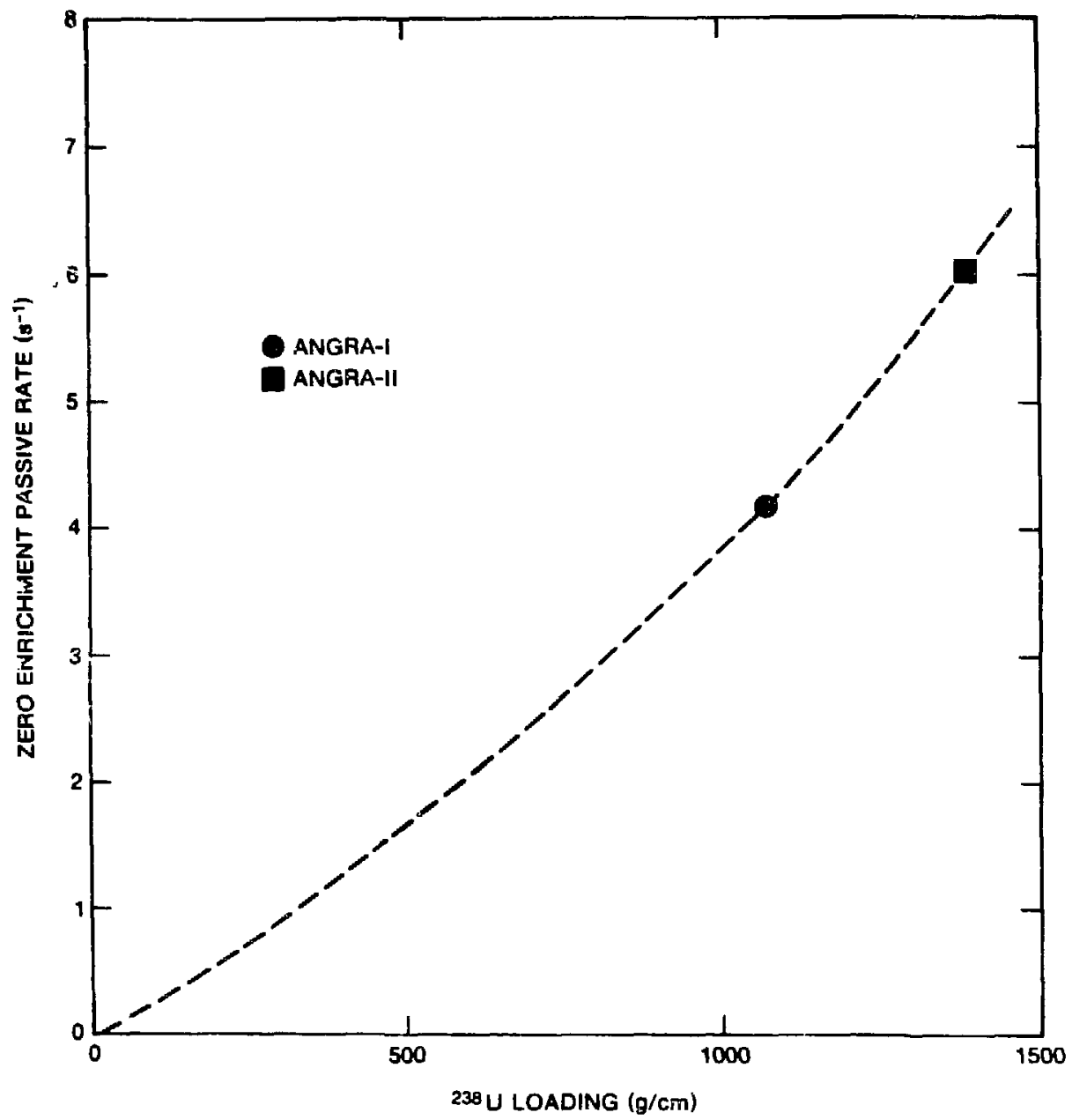

Fig. 9. Passive coincidence rates after correction for multiplication in $235 \mathrm{U}$ vs $238 \mathrm{U}$ loading.

in $R$, which can be compared with the expected value from counting statistics $0.28 \%(1 \sigma)$.

G. ANGR̈A-II Active Assay

We performed an active assay of ANGRA-II (depleted to $0.22 \%{ }^{235} \mathrm{U}$ ) to the induced-fission coincidence rate. This result was $R=24.8 \mathrm{~s}^{-1}$, but $\mathrm{w}$ such a low enrichment value, the thermal neutron absorption in ${ }^{238_{U}} \mathrm{U}$ and fast-fission fraction in the $238 \mathrm{U}$ become significant.

The power-function calibration curve (Fig. 5) does not give a good near the origin and it should only be used for enrichments greater than If we apply Eq. (1) $t_{1}$ the measured $R$, with $k_{1}=1.000$ and $k_{2}=0.7383$, we 
a mass value of $\sim 1 \mathrm{~g}{ }^{235} \mathrm{U} / \mathrm{cm}$ compared to the operator's tag value of 3.1 . If we want to appiy the neutron collar to depleted uranium fuel assemblies, it will be necessary to extend the calibration data down to this low loading.

\section{CONCLUSIONS}

\section{A. Electrical Noise}

There were no identifiable problems rrom electrical noise. We used a transformer to give $110 \mathrm{~V}$ and $60 \mathrm{~Hz}$ frofi $220 \mathrm{~V}$. During each measurement, we took at least five repeat cycles to check the data consistency. In two cases we observed a large $R+A$ or $A$ value, and the run was rejected.

B. Precision and Stability

The counting statistical precision for the coincidence rate $R$ for a $5 \times 200-s$ measurement was $0.7 \%$. This uncertainty increases to $1.49 \%$ in the mass calculation. The observed average absolute value for the mass residual was $1.49 \%$ for calibration method 1 .

Repeat runs for the same assernbly with no equipment or fuel movement gave an observed standard deviation of $0.55 \%$.

\section{Information from Operator}

In calibration method 1, we used the operator's value of the active length and uranium content in the reference assembly to obtain the fissile loading in the other assemblies.

In methods 2 and 3 , we are free of operator information if we determine the length using a scan or a separate gamma-ray measurement (for example, HM-4). 5

D. On-Line Use Potential

If the neutron collar is used by the plant operator, there is no need to make the repetitive setups of the equipment. Also, more time would be available for measuring each fuel assembly. For overnight ineasurements ( $8 \mathrm{~h}$ ), the statistical coincidence error reduces to $20.2 \%$. The intrinsic stability and positioning errors would probably linit the relative accuracy in the mass 
tc $20.7 \%$. This can be compared with the average absolute mass deviation of $1.49 \%$ obtained under inspection conditions at FEC.

\section{E. Inspector Use Evaluation}

The equipment performed very well under the difficult conditions of inspector field use. The equipment was shipped from Los Alamos to Brazil, was set up and taken apart seven times by the inspectors, was used by three different inspectors with only brief training on the instrument, was used both in situ (no fuel movement) and away from the high-density storage area, was subjected to about 10 power outages or disconnects, and was used during very humid and hot weather conditions.

None of these adverse conditions significantly degraded the results, and all of the measurements made during the six-month program are included in Tables $V$-IX. There were no equipment failures or repairs during the test period.

\section{ACKNOWLEDGMENTS}

We are grateful for the help received from CNEN Chairman, $R$. Alves, and B. Pontes in setting up the safeguards technical-exchange program. We extend our appreciation to J. Gilbride from the US consulate for assistance in the transfer of the equipment to Brazil; A. C. Berardo at FEC for assistance at the fuel fabrication plant; and J. C. Cabral and U. F. Vianna for their assistance in moving the fuel assemblies during the measurerent program. L. C. Galio at FEC designed and fabricated the collar support platform for scanning the fuel assemblies.

\section{REFERENCES}

1. H. 0. Menlove, "Description and Performance Characterisitics for the Neutron Coincidence Collar for the Verification of Reactor Fuel Assemblies," Los Alamos National Laboratory report LA-8939-MS (ISPO-142) (August 1981).

2. C. Beets, "Optimization of NDA Measurements in Field Conditions for Safeguards Purposes," Centre D'Etude de L'Energie Nucleaire Third Progress Report BLG553, Contract RB/2274 (January 1982). 
3. H. 0. Menlove and A. Keddar, "Field Test arid Evaluation of the IAEA Coincidence Collar for the Measurement of Unirradiated BWR Fuel Assemblies," Los Alamos National Laboratory report LA-9375-MS (ISP0-174) (Decenber 1982).

4. M. S. Krick and H. O. Meniove, "The High-Level Neutron Coincidence Counter (HLNCC): Users' Manual," Los Alamos Scientific Laboratory report LA-7779-M (1978).

5. G. R. Keepin, "IAEA Safeguards Equipment: Handbook of Current Use and Projected Requirements," International Atomic Energy Agency, Department of Safeguaids (February 1984). 


\section{APPENDIX}

\section{DATA COLLECTION AND STATISTICAL ANALYSES PROGRAM}

USING THE. HP-97 CALCULATOR

The software program used during the exercise is described in this appendix. The purpose of the program was to collect data in the cyclic mode; to calculate the estimated per cent standard deviation,

$$
0=\frac{\sqrt{(R+A)+A}}{R} \times 100 ;
$$

and to calculate the mean responses, $T$ and $R$, and the observed scatter ( $S$ ) about the mean. At the end of $n$ runs (or cycles), the standard deviation for the total counting time is calculated from

$$
\frac{\sqrt{\sigma \%}}{n}
$$

The inspector has a comparison of

\%\% (predicted deviation)

with

\section{S\% (observed scatter)}

at the time of the mecsurements.

In the program, subroutine $B$ is used for the passive measurement. The passive coincidence results are stored for use in subroutine $C$, which is used for the active measurement. The calibration constants, $a$ and $b$, and the background correction factors are directly written into the program. These values should not be changed as long as the present calibration constants are in use. An example of the readout format is given in Table A-I. 
TABLE A-I

DATA READOUI FURMAT FOR HP-97 DATA COLLECTION PROGRAM FOR A BWR ASSEMBLY

Passive Mode

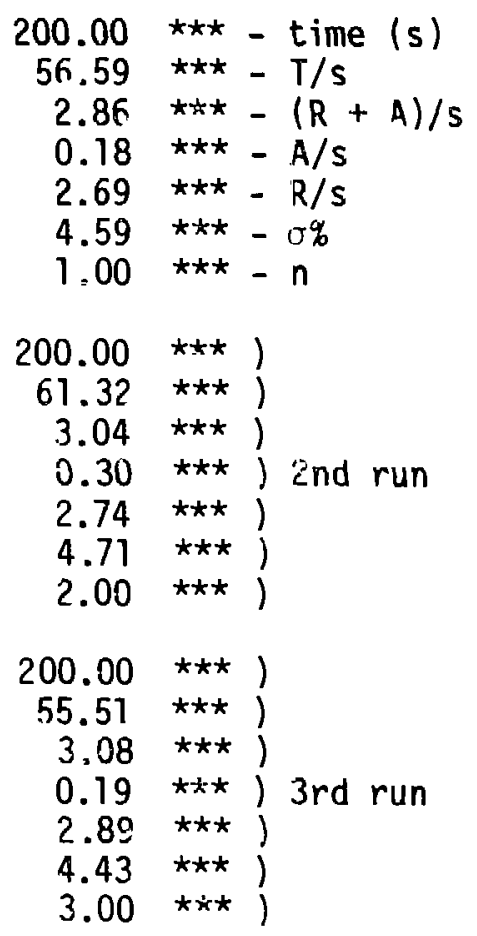

Press B

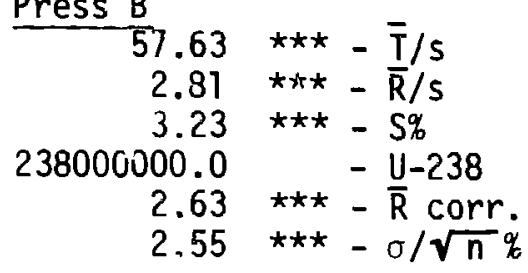

Press D (OF-innal)

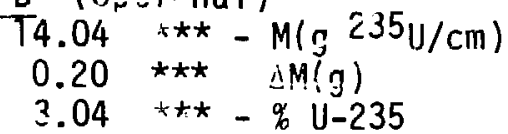

Active Mode

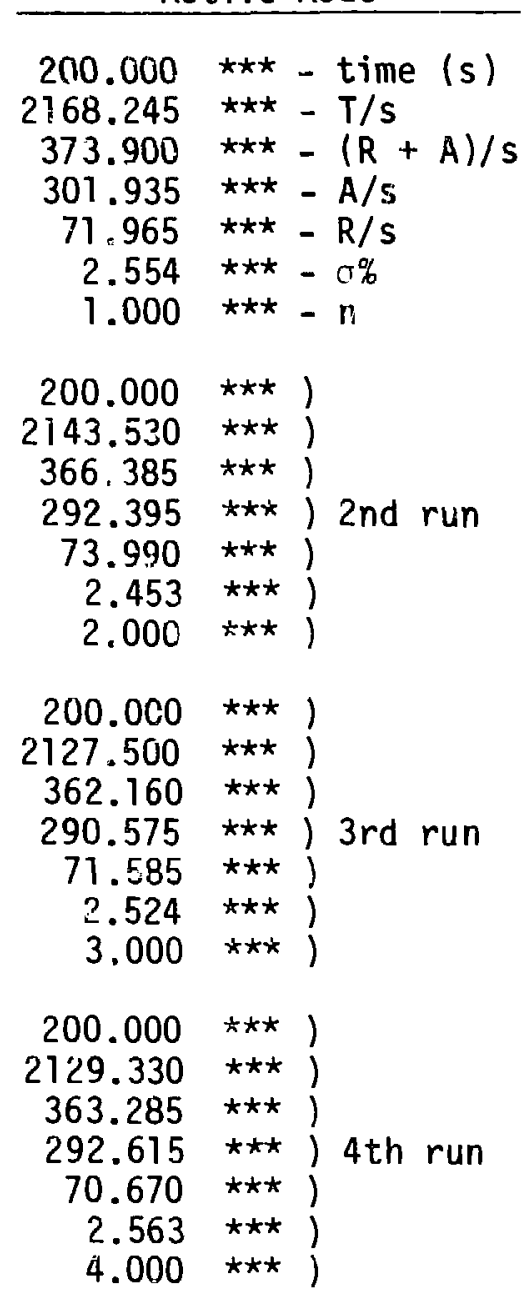

Press C

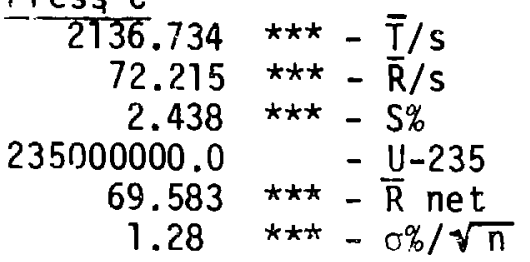


The HP-97 programs that include the ${ }^{235} \mathrm{U}$ mass calculation using the function $M=k_{2} a\left(k_{1} R\right)^{b}$ are given in Table $A-I I$ for PWR.

The mass calculation for the PWR case uses the equation

$$
M=k_{2} 0.001344\left(k_{1} R\right)^{2.135}
$$

and for BWR assemblies

$$
M=k_{2} 0.03177\left(k_{1} R\right)^{1.399} .
$$

The factors $k_{1}$ and $k_{2}$ are defined in Sec. VI.D of this report.

If subprogram $D$ for the mass calculation is to be used during the inspection, then the inspector must store the factors in the HP-97 as follows:

$$
\begin{aligned}
& k_{1}+\text { store }(S T \cap) \text { in Register } C, \\
& k_{2} \text { + store }(S T O) \text { in Register } D, \\
& k_{3}+\text { store }(S T O) \text { in Register E (optional), }
\end{aligned}
$$

where

$$
k_{3}=\frac{\text { Av Enrichment }}{235 \mathrm{Vg} / \mathrm{cm}} \text {. }
$$

It is only necessary to enter $k_{3}$ if the inspector wants a printout of the $235 \mathrm{U}$ enrichment. Otherwise, zero will be printed after the $235 \mathrm{U}$ linear density.

Note that Register A contains the passive coincidence rate (automatically stored in Register A when subprogram B, passive, is used). If the user wants 
TABLE A.-II

HP-97 PROGRAM FOR FWR ASSEMBLIES

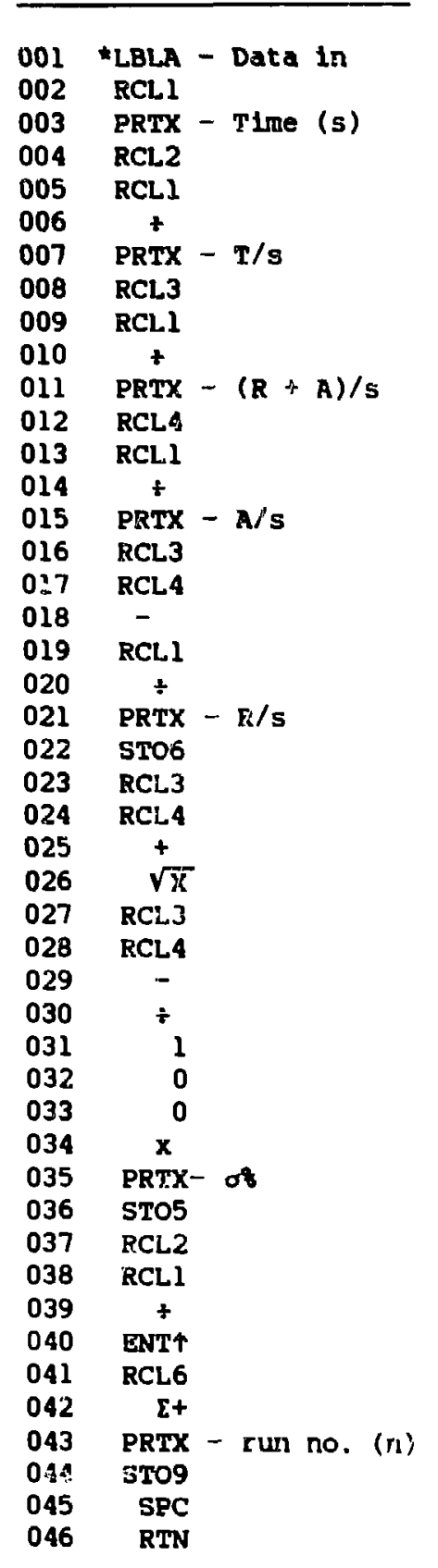

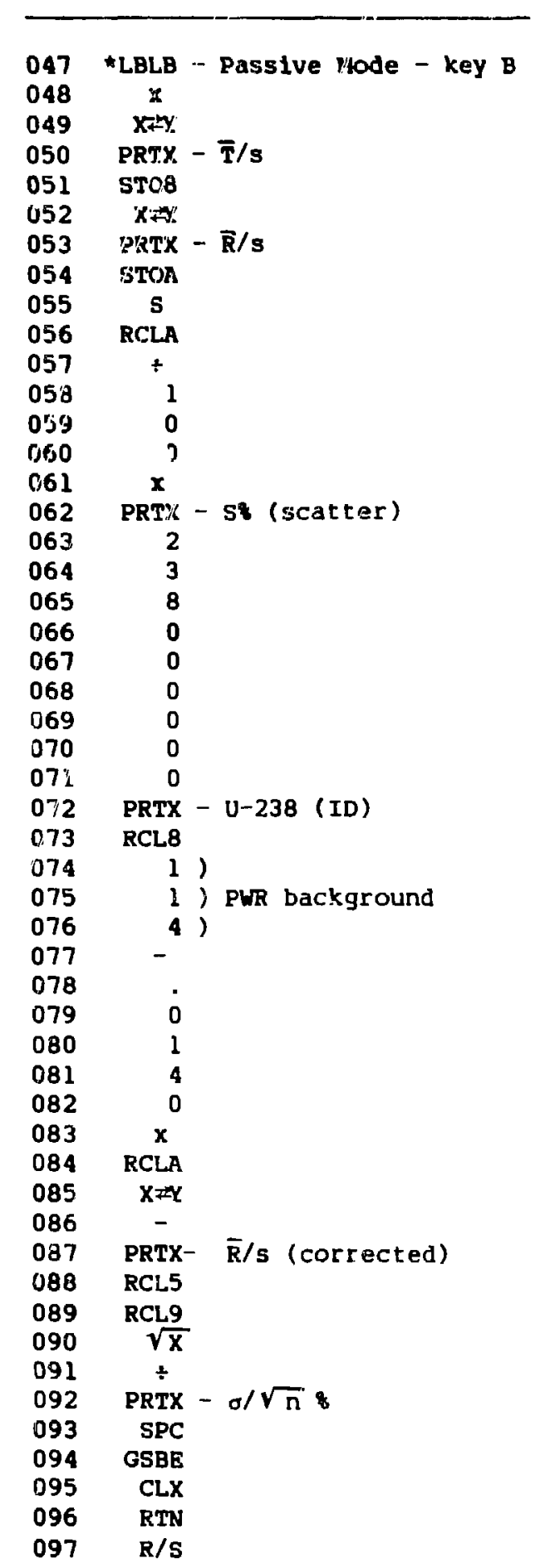


TAELE A-I I (cont)
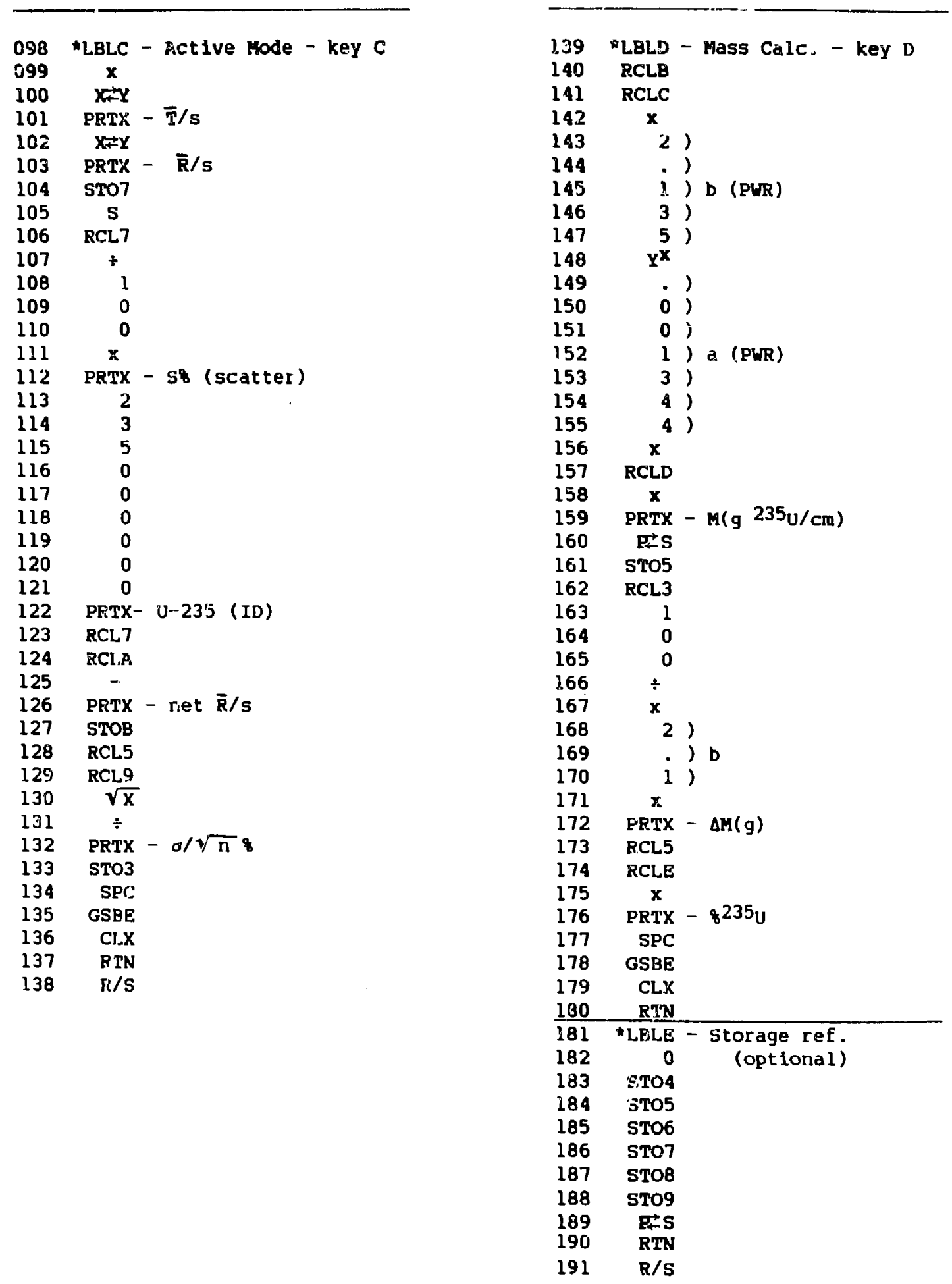
to make a series of active measurements without the corresponding passive assays, then an average value of the total passive coincidence rate can be stored (STO) in Register A manually.

The protected registers contain the following:
$A-$ Ris (passive) | automatic from
$B-R / s$ (active) subprograms $B$ and $C$
$C-k_{1}$ (response corrections) must be entered
$D-k_{2}$ (calib. normalization)
by user
$E-k_{3}$ (enrichment factor)
(1.00 optional).

The single HP-97 magnetic card (both sides) for the HP-97 contains ali of the programs needed for routine operation of the coincidence collar for a speciric type of fuel assembly. The constants $a$ and $b$ and background parameters are written into the program, and thus separate cards are needed for PWR and BWR applications. Each card contains five subprograms with the following functions:

1. Program key A (cyclic data collection triggered by the HEC-100 microprocessor)

2. Program key B (passive measurement summary, background correction, and error - ${ }^{238} U$ )

3. Program key $\mathrm{C}$ (active measurement summary, background correction, and error $\left.-{ }^{235} U\right)$

4. Program key D $\left({ }^{235} \mathrm{U}\right.$ mass calculation with calibration parameters and normalizations)

5. Program key E (clears statistics for aborted cyclic runs)

These programs are listed in Table A-II. The HP-97 keys A-E serve the dual purpose as storage registers (STO) and program keys. 